УДК 378.091.12.011.3-051:80/.81'25:005.336.4(4)

UDC 378.091.12.011.3-051:80/.81'25:005.336.4(4)

DOI: $10.31475 /$ ped.dys.2020.29.12

СВГЕН ДОЛИНСЬКИЙ,

доктор педагогічних наук, доцент

(Украӥна, Хлельницький, Хлельницький національний університет, вул. Інститутська, 11)

IEVGEN DOLYNSKIY,

Doctor of Pedagogical Sciences, Associate Professor (Ukraine, Khmelnytskyi, Khmelnytskyi National University,

Instytutska St., 11)

ORCID: 0000-0003-4074-4648

\title{
Особливості європейського досвіду навчання теорії та практики перекладу майбутніх іноземних філологів
}

\section{European Experience Features of Translation Theory and Practice Teaching of Future Foreign Philologists}

В статті проаналізовано досвід профбесійної підготовки майбутніх перекладачів із використанням інфбормаційно-колунікаційних технологій у закладах вищої освіти краӥн Європейського Союзу. У світі існує розгалужена мережа перекладацької освіти, до якої входять державні університети, державні і приватні школи й інститути перекладачів та курси. Існує декілька основних моделей підготовки перекладачів. $B$ західноєвропейських країнах, найпоширенішили е кваліфбікаційні рівні: "бакалавр", "магістр", "доктор фбілософбїі. Студент має можливість створення індивідуального пакета курсів. Університети мають високий рівень матеріально-технічного забезпечення. Практична складова програл має активну $i$ пасивну виробничі практики. Розглянуто особливості профбесійної підготовки перекладачів $в$ європейських краӥнах. Урахування позитивних складових зарубіжного досвіду покращить якість пробесійної підготовки майбутніх перекладачів в інфборлаційно-освітньому середовищі університету.

Ключові слова: пробесійна підготовка, майбутні перекладачі, заклади вищої освіти, крайни Європейського Союзу.

The article analyzes the experience of professional training of future translators with the use of information and communication technologies in higher education institutions of the European Union. Requests from developed European countries form a new level of translation. Today, there is an extensive network of translation education in the world, which includes public universities, public and private schools and translation institutes, and courses. There are several basic models for training translators. Educational programs and qualification characteristics of graduates are adjusted according to the needs of the translation services market. 215 higher education institutions train translators in Europe. In Western European countries, the most common are the following qualification levels: "bachelor", "master», "doctor of philosophy".

The student has the opportunity to create an individual package of courses. Getting quality education by future translators requires significant resources and contributions. Universities have a high level of logistics. The practical component of the programs has active and passive production practices. The training of future translators in universities is based on the principles of scientificity, continuity and continuity of education, taking into account the capabilities of modern information technology.

Interactive information technologies that develop translators' communication skills are common in British universities. In France, multidisciplinary translators, specialists in localization, terminology, legal translation, translators of official documents, etc. are currently being trained. Particular attention is now being paid to training translators in the use of SAT technologies. In Austria, translators are trained at three universities in the country.

The effectiveness of measures to improve the quality of professional training of future translators in the information and educational environment of the university depends on the positive components of foreign experience.

Keywords: professional training, future translators, institutions of higher education, countries of the European Union. 
Вступ / Introduction. Важливим для української системи вищої педагогічної освіти є досвід зарубіжних країн. Посилюють важливість суперечності, виявлені за результатами аналізу проблематики і практики підготовки майбутніх перекладачів в університетах, зокрема між: потребою суспільства в якісній професійній підготовці кваліфікованих перекладачів для різних галузей та недостатнім науковим обгрунтуванням цього складника в системі професійної освіти; наявністю різноманітних засобів інформаційно-комунікаційних технологій та їннім неналежним застосуванням у межах традиційної підготовки майбутніх перекладачів. Так, впровадження прогресивного европейського досвіду в професійну підготовку майбутніх перекладачів із використанням інформаційно-комунікаційних технологій у закладах вищої освіти України зумовлюе актуальність питання.

Мета та завдання/Aim and Tasks. Метою дослідження $е$ виявлення особливостей професійної підготовки майбутніх перекладачів із використанням інформаційно-комунікаційних технологій у закладах вищої освіти країн Свропейського Союзу та обгрунтування можливостей використання прогресивних ідей у вітчизняних закладах вищої освіти.

Методи/Methods. Для досягнення мети дослідження використовувалися такі методи дослідження: аналіз, синтез, узагальнення. Важливим е використання компаративного методу для виявлення подібних та відмінних підходів щодо професійної підготовки майбутніх перекладачів із використанням інформаційно-комунікаційних технологій у закладах вищої освіти країн Свропейського Союзу. У роботі використано прогностичний метод - для обгрунтування напрямів використання прогресивних ідей професійної підготовки майбутніх перекладачів у закладах вищої освіти країн Європейського Союзу; європейського досвіду професійної підготовки майбутніх перекладачів із використанням інформаційно-комунікаційних технологій в Україні.

Результати / Results. Нами проаналізовано досвід професійної підготовки майбутніх перекладачів із використанням інформаційно-комунікаційних технологій у закладах вищої освіти країн Свропейського Союзу.

Запити розвинених країн Свропи формують новий рівень вивчення мов, прискорений розвиток перекладу як навчальної дисципліни. Причинами цього є інтеграційні процеси, якісно новий (за останні десять років) розвиток засобів комп'ютерних і комунікаційних зв’язків, розвиток освіти і туризму.

О. Сергеєва, зазначає, що «близько 215-ти закладів вищої освіти готують перекладачів в Європі. У Великій Британії таких закладів 28 , хоча донедавна їх було лише п'ять. Дев’ятнадцять із сучасних університетів готують усних перекладачів (interpreters), решта - письмових (translators). Зокрема, програми підготовки усних перекладачів існують у Батському університеті, Единбурзькому університеті Геріота Вотта, Лідському університеті, у Лондонському столичному університеті, Міддлсекському, Манчестерському, Ньюкаслському, Солфордському університетах та ін. Програми підготовки письмових перекладачів запропоновані в таких університетах: Шеффрілдському, Суррейському, Бристольському, Суонсійському, Ворвікському, Вестмінстерському, Лондонському, Астонському, Бірмінгемському, Батському тощо» (Сергеєва О., 2012, c. 88).

«У Великій Британії, як і в інших західноєвропейських країнах, найпоширенішими вважаються такі кваліфікаційні рівні: «бакалавр» (Bachelor), «магістр» (Master), «доктор філософіï» (Doctor of Philosophy).

Важливим елементом освітнього процесу в британських університетах є надання студентові можливості створення індивідуального пакета курсів, необхідних для отримання певної професії, зокрема професії перекладача» (Долинський Є., 2014, с. 147).

Отримання якісної освіти майбутніми перекладачами вимагає значних ресурсів і внесків. Британські університети мають високий рівень матеріально-технічного забезпечення, оскільки процес розвитку закладів вищої освіти пов'язаний із постійним удосконаленням та ефективністю використання наявних матеріальних ресурсів. Університетські бібліотеки володіють великими фондами літератури та освітніх інформаційних ресурсів (Сергеєва О., 2012).

«Професійна підготовка усних і письмових перекладачів у Великій Британії відбуваеться за незалежними магістерськими програмами. Основним елементом педагогічних інформаційних технологій є компютерні технології, розроблені для оптимізації навчання. Серед їх переваг у процесі навчання майбутніх перекладачів можна виділити: сучасне інформативне та грунтовне наукове забезпечення, можливість оперативних змін у плануванні та організації навчання, комбінаторність і здатність вибирати засоби та форми навчання, можливість моделювання різноманітних професійних ситуацій, організація чіткої взаемодії із студентами, онлайнконсультації та оцінювання, впровадження особистісного підходу, ефективний обмін досвідом, реалізація ідеї неперервної освіти, створення конкуренції навчальних курсів, зменшення витрат навчального часу» (Долинський Є., 2014, с. 148; 389). 
Ми погоджуемося з М. Прадівляним, що впровадження IT-засобів у жодному випадку не применшить ролі викладача у навчанні, навпаки, вимагатиме від останнього «здатності використовувати всі засоби для досягнення продуктивної самостійної діяльності студентів» (Долинський Є., 2013, с. 92; 344).

«Практична складова програм підготовки майбутніх перекладачів в університетах Великої Британії містить такий елемент, як проходження активної і пасивної виробничої практики. Остання е завершальним етапом формування фахівця, упродовж якого відбувається закріплення теоретичних знань та практичних умінь і формуються навички професійної діяльності. За словами британського вченого Дж. Річардза, професора перекладу університету міста Бат, практика $e$ природним методом визначення мотиваційних, професійних і життевих пріоритетів студентів. Потрапляючи у нове середовище, наближене до реального, вони його досліджують і вивчають. Отже, підсвідомо формуються вміння і навички професійної діяльності» (Долинський Є., 2014, c. 147).

«Британський університет відкритої освіти, заснований указом Ї̈̈ Величності Королеви Великобританії у 1969 році. Мета його створення - надати можливість отримати освіту людям, охочим вчитися в зручному для них місці і в зручний час. Відкритий університет - найбільший університет Великої Британії, в якому навчаеться близько 200000 студентів» (Відкритий університет..., n.d.).

Якість навчального процесу у Відкритому університеті оцінено на «відмінно» британським Агентством якості вищої освіти (Quality Assurance Agency for Higher Education). За підсумками проведеного державою в 2005 році національного опитування задоволеності випускників, Відкритий університет посів перше місце серед Британських Університетів. «Як мультимедійне доповнення навчальних матеріалів на паперових носіях інформації, використовуються різні телевізійні та радіопрограми, що е спільною роботою з компанією ВВС» (Долинський Є., 2014, c. 148; 391). В університеті використовуються методи дистанційного навчання, відео, аудіоматеріали супроводжуються підтримкою тьютора $\mathrm{i}$ регулярними очними груповими семінарами.

«У Британських університетах Бристоля, Бірмінгема, Астона і Суррея розповсюдженими є інтерактивні інформаційні технології, що розвивають комунікативні навички перекладачів» (Долинський Є., 2014, с. 148).

«Серед засобів мультимедіа, що використовуються під час професійної підготовки майбутніх перекладачів, е: мультимедіа-презентація; слайд-шоу; електронний звіт; мультимедіа доповідь; електронний журнал; віртуальний тур; flash- та shockwave-ігри (навчальні ігри, розміщені як в інтернеті (онлайн), так і на різних носіях (офлайн); навчальні мультимедіа та лінгвістичні мультимедіа системи; мультимедійні інтернет-ресурси» (Сергеєва О., 2012, с. 111).

З метою інтенсифікації та поліпшення якості професійної підготовки майбутніх перекладачів у закладах вищої освіти «Лондона, Мідлсекса, Бата та інших, запроваджено використання електронних засобів віртуальної комунікащії (Сергеєва О., 2012, с. 112).

Таким чином, підготовка майбутніх перекладачів у британських університетах базуеться на принципах науковості, наступності та неперервності навчання, $з$ урахуванням можливостей сучасних інформаційних технологій.

У Франції на сьогодні готують різногалузевих перекладачів, спеціалістів з локалізації, термінології, юридичного перекладу, перекладачів офіційних документів тощо. Особлива увага зараз звертається на навчання перекладачів використанню CAT-технологій (CAT - ComputerAided Translation - технології автоматизованого перекладу) у перекладі, оволодіння професійним програмним забезпеченням.

«У Франції найвідомішими закладами вищої освіти, де здійснюють підготовку перекладачів, $є$ школа перекладу ESIT (École Supérieure d'Interprètes et de Traducteurs) та інститут ISIT (Institut Supérieur d'Interprètation et de Traduction), розташовані у Парижі», - зазначається у статті К. Скиби (Скиба К., 2014, с. 83).

Як зазначае К. Скиба, «заслуговуе на увагу те, що останнім часом у країні спостерігаеться тенденція до збільшення кількості закладів освіти, які пропонують курси усного чи письмового перекладу. Підраховано, що є понад 60 різних курсів, а близько 20 з них завершуються отриманням диплома про спеціальну вищу освіту (DESS). Спеціалізованому перекладу (усному чи письмовому) навчають у вищих закладах освіти різного типу - як в державних, так і в приватних. За даними міністерства освіти Франції, щонайменше 15 університетів проводять підготовку перекладачів (університети Лілля, Тулузи, Монпелье, Гренобля, Парижу та ін.)» (Скиба К., 2014, c. 83).

Аналізуючи міжнародний досвід підготовки майбутніх перекладачів у Франції, Л. Максименко зазначає, що «Вища школа усних і письмових перекладачів (ESIT) у Парижі вирізняеться 
оригінальністю своєї концепції перекладу і методики професійної підготовки, розробленої ії засновниками - Д. Селескович і М. Ледерер та їхніми послідовниками. Відповідно до їхньої інтерпретаційної теорії, перекладач повинен передавати ідеї, а не перекодовувати слова. Тому увага сконцентрована на навчанні методів і прийомів передачі думки. Програми мають практичне спрямування, не переобтяжені вивченням теоретичних дисциплін та інших теорій перекладу. Школа виконуе загальну методологічну підготовку, що дозволяе перекладати тексти різних жанрів, застосовуючи методи й прийоми професійного перекладу. Викладання іноземних мов не практикуеться, тому приймають лише студентів, які вільно володіють рідною і двома іноземними мовами, але необхідно пройти вступний іспит» (Максименко Л., 2015, с. 77).

У дослідженні Н Левицької знаходимо, що «в Австрії професійна підготовка перекладачів здійснюеться в трьох університетах країни (Відень, Грац, Інсбрук). Найпопулярнішим є інститут усних і письмових перекладачів при Віденському університеті. У всіх університетах навчання перекладачів відбуваеться 3 послідовним здобуттям ступенів «бакалавр», «магістр». Усі університети пропонують бакалаврат і магістратуру в галузі перекладу. Бакалаврські програми містять у собі такі лекційні курси як «Вступ до спеціальності», «Основи мовознавства», «Основи економіки та права», «Країнознавство». Магістерські програми передбачають опанування студентами теоретичних знань зі спеціалізованих дисциплін» (Левицька Н., 2011).

Як зазначае А. Леонова, що «у навчальних планах Віденського університету (Universität Wien) і університету в Граці (Karl-Franzens-Universität Graz) багато уваги приділяють інформаційним технологіям. Віденський університет пропонуе майбутнім перекладачам два обов'язкові модулі: «Професійна комунікація» і «Міжкультурна комунікація та вступ в професію перекладача». Ці модулі передбачають вивчення особливостей різних видів текстів, методів термінологічного пошуку і зберігання даних, основ міжкультурної комунікації, навчання роботі з пошуковими системами в мережі Інтернет, з довідковими матеріалами та словниками. Водночас вводяться дисципліни, які сприяють формуванню організаційно-управлінських компетентностей: «Міжкультурний менеджмент», «Менеджмент різноманітності», «Проект-менеджмент», «Мовні технології та менеджмент знань» (Леонова А., 2012, с. 123).

Цікавою в цьому питанні е програма університету в Граці, що пропонуе як обов'язковим модуль «Комунікаційний менеджмент і основи інформаційних технологій», мета якого - отримання базових знань і навичок у сфері IT у перекладі та вдосконалення лінгвістичної і текстової компетенцій.

Дисципліна «Основи інформаційних технологій» ознайомлюе студентів 3 можливостями застосування IT і корпусів текстів у перекладі, з методами пошуку інформації в комп'ютерних мережах, студенти отримують навички роботи з пакетом програм Microsoft Office та деякими системами машинного перекладу.

Університет в Інсбруку (Leopold-Franzens-Universitat Innsbruck) також вводить у програму підготовки перекладачів обов'язковий модуль «Менеджмент термінології», метою якого є навчання грамотному використанню сучасних інформаційних технологій, оволодіння методами пошуку, зберігання та організації інформації (Амеліна С., 2013).

Обговорення/Discussion. «Сьогодні у світі існуе розгалужена мережа перекладацької освіти, до якої входять державні університети, державні і приватні школи й інститути перекладачів та курси. Результати аналізу досліджень дозволяють зробити висновок про те, що на сучасному етапі у світі існуе декілька основних моделей підготовки перекладачів» (Максименко Л., 2015, с. 74).

«Найбільш розповсюдженою е підготовка перекладачів на грунті загальної лінгвістичної освіти, яка спрямована на оволодіння перекладацькими навичками та вміннями. До таких закладів приймають студентів із першим рівнем університетської освіти, які володіють двома іноземними мовами. Разом із курсом перекладу вони удосконалюють володіння рідною мовою. Курси з практики іноземних мов здебільшого відсутні, натомість е курс з удосконалення культури мовлення першою і другою іноземними мовами (Вища школа перекладачів у Парижі, Школа перекладачів у Женеві, Університет Адама Міцкевича в Польщі, Тартуський університет в Естонії, Університет Хільдесхайм у Німеччині, Болонський університет (Школа сучасних мов для перекладачів) в Італії, Даремський i Манчестерський університети в Англії та ін.)» (Максименко Л., 2015, с. 74-75).

У праці Л. Максименко, зустрічаємо, що «модель підготовки перекладачів на базі середньої освіти спрямована на вивчення мов і перекладацьких дисциплін. Після здобуття середньої освіти абітурієнтів зараховують до університетів і шкіл, у яких одна з іноземних мов вивчаеться від самого початку (перекладацькі школи Бельгії, Балтійська Міжнародна Академія в Латвії, Фленсбурзький університет у Німеччині, Університет Костянтина Філософа у Нітрі (Словаччина), Люблянський університет у Словенії, Вальядолідський університет в Іспанії, факультет усного і 
письмового перекладу в Женевському університеті (Швейцарія) тощо).

I, нарешті, - модель, що передбачае отримання перекладацької підготовки випускниками 3 вищою професійною освітою першого та другого рівнів, розрахованої на вивчення іноземної мови фахівцями з різних галузей. Зазвичай, такі програми доповнюються курсом із практики однієї іноземної мови і курсом письмового перекладу (перекладацькі школи у Нідерландах, Швейцарії, Франції).

Результати аналізу стану підготовки перекладачів країн, як-от: Велика Британія, Франція, Австрія, дають можливість зробити висновок про те, що освітні програми та кваліфікаційні характеристики випускників коригуються відповідно до потреб ринку перекладацьких послуг» (Максименко Л., 2015, с. 74-75).

«Характерним е той факт, що більшість перекладацьких шкіл Західної Європи мають на меті підготовку перекладачів із двох іноземних мов на рідну мову зі спеціальностей: усний переклад (послідовний і синхронний) на конференціях і письмовий переклад широкого профілю, або за різними спеціалізаціями (науково-технічний, публіцистичний, юридичний, економічний, художній)» (Максименко Л., 2015, с. 76).

Висновки / Conclusions. Отже, ефективність заходів щодо покращення якості профоесійної підготовки майбутніх перекладачів в інформаційно-освітньому середовищі університету багато в чому залежить від урахування позитивних складових зарубіжного досвіду у цій сфері професійної освіти.

В університетах України програми підготовки майбутніх перекладачів мають інтегрований характер і не диференціюються залежно від видів перекладацької діяльності, що не відповідає міжнародним стандартам та світовій практиці.

Нами викладено результати теоретичного аналізу зарубіжного досвіду професійної підготовки майбутніх перекладачів з використанням засобів ІКТ в европейських університетах. У таких університетах спостерігаеться активне впровадження нововведень, спрямованих на формування інформаційно-освітнього середовища університетів, забезпечення індивідуалізації, доступності та якості навчання. Спостерігається розвиток тенденщій щодо переходу від групових форм і методів навчання до індивідуально-групових із використанням інтерактивних i мультимедійних технологій, що поєднуються в інформаційно-освітньому середовищі університету. З'ясовано, що освітній процес не обмежуеться вивченням теоретичних аспектів перекладознавства та практикою перекладу, а охоплюе дисципліни, що дають можливість студентам ознайомитись з особливостями функціонування програмного забезпечення, задіяного в процесі комп'ютерного перекладу текстів.

Вивчивши досвід европейських країн, вважаємо за потрібне більше уваги приділяти практиці, використанню інформаційно-комунікаційних технологій. Зокрема при вивченні дисциплін «Практика перекладу», «Ділова англійська мова», «Переклад науково-технічних текстів», «Переклад громадсько-політичної літератури».

Список використаних джерел і літератури:

Амеліна, С. М. (2011). Особливості теорії і практики перекладу в підготовці перекладачів у ФРН. Проббесійна педагогічна освіта у поліпроббільнолу навчальнолу закладі. Взято з http://journals.nubip.edu.ua/index.php/Pedagogica/article/viewFile/2907/2846 [in Ukrainian].

$\begin{array}{lllll}\text { Відкритий } & \text { університет } & \text { (Велика } & \text { Британія). } & \text { Взято }\end{array}$ https://uk.wikipedia.org/wiki/\%D0\%92\%D1\%96\%D0\%B4\%D0\%BA\%D1\%80\%D0\%B8\%D1\%82\%D0\%B8\%D0\%B9_\% D1\%83\%D0\%BD\%D1\%96\%D0\%B2\%D0\%B5\%D1\%80\%D1\%81\%D0\%B8\%D1\%82\%D0\%B5\%D1\%82_(\%D0\%92\%D0\% B5\%D0\%BB\%D0\%B8\%D0\%BA\%D0\%B0_\%D0\%91\%D1\%80\%D0\%B8\%D1\%82\%D0\%B0\%D0\%BD\%D1\%96\%D1\%8F) [in Ukrainian].

Долинський, Є. В. (2013). Досвід використання новітніх інформаційних технологій у підготовці майбутніх перекладачів в університетах Великої Британії. Інфборлаційні технології в освіті, 17, 91-98. Взято 3 http://ite.kspu.edu/webfm_send/742 [in Ukrainian].

Долинський, С. В. (2014). Особливості формування інформатичної компетентності майбутніх перекладачів в університетах Європейського Союзу. Порівняльна професійна педагогіка, 4 (3), $145-149$ [in Ukrainian].

Левицька, Н. В. (2011). Концептуальні засади професійної підготовки перекладачів в країнах Західної Свропи. Вісник Національної акаделї̈ Державної прикордонної служби Украӥни, 5. Взято 3 http://nbuv.gov.ua/UJRN/Vnadps_2011_5_16 [in Ukrainian].

Леонова, А. С. (2012). Специфика информационной подготовки переводчика: требования рынка. Историческая и социально-образовательная мьсль, 3 (13), 122-124 [in Russian].

Максименко, Л. О. (2015). Зарубіжний досвід організації підготовки перекладачів на сучасному етапі розвитку вищої освіти. Вісник Чернігівського національного педагогічного університету. Сер.: Педагогічні науки, 131, 74-78. Взято з http://nbuv.gov.ua/UJRN/VchdpuP 201513119 [in Ukrainian].

Сергеєва, О. В. (2012). Професійна підготовка перекладачів в університетах Великої Британії: дис. ... канд. пед. наук: 13.00.04. Хмельницький [in Ukrainian].

Скиба, К. М. (2014). Професійна підготовка перекладачів у країнах-учасницях Болонського процесу. 
Педагогічний процес: теорія і практика, 4, 80-86. [in Ukrainian].

\section{References:}

Amelina, S. M. (2011). Osoblyvosti teorii i praktyky perekladu v pidhotovtsi perekladachiv u FRN [Features of the Theory and Practice of Translation in the Training of Translators in Germany]. Profesiina pedahohichna osvita u poliprofilnomu navchalnomu zakladi - Professional Pedagogical Education in a Multidisciplinary Educational Institution. Retrieved from http://journals.nubip.edu.ua/index.php/Pedagogica/article/viewFile/2907/2846 ( [in Ukrainian].

Vidkrytyi universytet (Velyka Brytaniia) [Open University (UK)]. Retrieved from https://uk.wikipedia.org/wiki/\%D0\%92\%D1\%96\%D0\%B4\%D0\%BA\%D1\%80\%D0\%B8\%D1\%82\%D0\%B8\%D0\%B9_\% D1\%83\%D0\%BD\%D1\%96\%D0\%B2\%D0\%B5\%D1\%80\%D1\%81\%D0\%B8\%D1\%82\%D0\%B5\%D1\%82_(\%D0\%92\%D0\% B5\%D0\%BB\%D0\%B8\%D0\%BA\%D0\%B0_\%D0\%91\%D1\%80\%D0\%B8\%D1\%82\%D0\%B0\%D0\%BD\%D1\%96\%D1\%8F) [in Ukrainian].

Dolynskyi, Ye. V. (2013). Dosvid vykorystannia novitnikh informatsiinykh tekhnolohii u pidhotovtsi maibutnikh perekladachiv $\mathrm{v}$ universytetakh Velykoi Brytanii [Experience in Using the Latest Information Technologies in the Training of Future Translators in UK Universities]. Informatsiini tekhnolohii $v$ osviti Information Technologies in Education, 17, 91-98. Retrieved from http://ite.kspu.edu/webfm_send/742 [in Ukrainian].

Dolynskyi, Ye. V. (2014). Osoblyvosti formuvannia informatychnoi kompetentnosti maibutnikh perekladachiv v universytetakh Yevropeiskoho soiuzu [Features of Formation of Computer Competence of Future Translators in Universities of the European Union]. Porivnialna profesiina pedahohika - Comparative Professional Pedagogy, 4 (3), 145-149. [in Ukrainian].

Levytska, N. V. (2011). Kontseptualni zasady profesiinoi pidhotovky perekladachiv v krainakh Zakhidnoi Yevropy [Conceptual Principles of Professional Training of Translators in Western Europe]. Visnyk Natsionalnoi akademii Derzhavnoi prykordonnoi sluzhby Ukrainy - Bulletin of the National Academy of the State Border Guard Service of Ukraine, 5. Retrieved from http://nbuv.gov.ua/UJRN/Vnadps_2011_5_16 [in Ukrainian].

Leonova, A. S. (2012). Specifika informacionnoj podgotovki perevodchika: trebovaniya ry'nka [Specificity of Information Preparation of a Translator: Market Requirements]. Istoricheskaya i socialno-obrazovatelnaya my'sl Historical and Socio-Educational Thought, 3 (13), 122-124.

Maksymenko, L. O. (2015). Zarubizhnyi dosvid orhanizatsii pidhotovky perekladachiv na suchasnomu etapi rozvytku vyshchoi osvity [Foreign Experience in Organizing the Training of Translators at the Present Stage of Development of Higher Education]. Visnyk Chernihivskoho natsionalnoho pedahohichnoho universytetu. Ser.: Pedahohichni nauky - Bulletin of Chernihiv National Pedagogical University. Ser.: Pedagogical Sciences, 131, 7478. Retrieved from http://nbuv.gov.ua/UJRN/VchdpuP 2015 131 19 [in Ukrainian].

Sierhieieva, O. V. (2012). Profesiina pidhotovka perekladachiv $v$ universytetakh Velykoi Brytanii [Professional Training of Translators in British Universities]. Candidate's thesis. Khmelnytskyi [in Ukrainian].

Skyba, K. M. (2014). Profesiina pidhotovka perekladachiv u krainakh-uchasnytsiakh Bolonskoho protsesu [Professional Training of Translators in the Countries Participating in the Bologna Process]. Pedahohichnyi protses: teoriia i praktyka - Pedagogical Process: Theory and Practice, 4, 80-86. [in Ukrainian].

Дата надходження статті: «13» жовтня 2020 р.

Стаття прийнята до друку: «18» грудня 2020 р.

Долинський Свген - професор кафедри германської філології та перекладознавства Хмельницького національного університету, доктор педагогічних наук, доцент

Dolynskiy Ievgen - Professor of the Department of German Philology and Translation Studies of Khmelnytskyi National University, Doctor of Pedagogical Sciences, Associate Professor

\section{Цитуйте цљю статтю як:}

Долинський, Є. (2020). Особливості европейського досвіду навчання теорії та практики перекладу майбутніх іноземних філологів. Педагогічний дискурс, 29, 88-93. doi: 10.31475/ped.dys.2020.29.12.

\section{Cite this article as:}

Dolynskiy, I. (2020). European Experience Features of Translation Theory and Practice Teaching of Future Foreign Philologists. Pedagogical Discourse, 29, 88-93. doi: 10.31475/ped.dys.2020.29.12. 